\title{
Plant food allergy - is it time to see the seeds?
}

\author{
Sigrid Sjölander*, Anna Rylander, Otti Bengtsson-Gref, Peter Brostedt, Hillevi Englund \\ From Food Allergy and Anaphylaxis Meeting 2014 \\ Dublin, Ireland. 9-11 October 2014
}

Allergic reactions to fruits and vegetables are frequently observed, however skin prick tests and serological analyses may not always confirm allergy. Recent advances have identified the seeds as potential allergen sources. Seeds are generally rich in storage proteins like $7 \mathrm{~S} / 11 \mathrm{~S}$ globulins and $2 \mathrm{~S}$ albumins, which are allergens known to be linked to severe reactions. For a number of plant food, seeds are ingested, both intentionally and accidentally. In addition, seeds content can potentially leak during food processing leading to unintentional storage protein contamination.

In this study, three unrelated seed rich species were chosen: strawberry, tomato and bell pepper. For tomato storage proteins have been described, but not for strawberry and bell pepper. Here, fruit pulp and seed were separated, extracted and analyzed. Analytical gel filtration revealed different protein patterns in pulp and seeds for all three species, confirmed also by SDS-PAGE analysis.

IgE-analyses towards pulp and seed extract respectively with sera from patients with documented allergy were performed. Differences in IgE-binding to seeds and pulp extracts were demonstrated for all patient sera.

Given the near 20 nuts, legumes, seeds and grains with IUIS-registered storage proteins, it seems likely that there are storage proteins present also in seeds from other fruits and vegetables. Here, the protein patterns for pulp and seed differed in the biochemical analyses. Further, clear differences in IgE-binding towards seed and pulp were observed in sera from 20 allergic patients, encouraging further studies revealing the clinical importance of seeds in plant food allergy.

Published: 30 March 2015

Thermo Fisher Scientific, R\&D, Uppsala, Sweden
doi:10.1186/2045-7022-5-S3-P26

Cite this article as: Sjölander et al:: Plant food allergy - is it time to see the seeds? Clinical and Translational Allergy 2015 5(Suppl 3):P26.
Submit your next manuscript to BioMed Central and take full advantage of:

- Convenient online submission

- Thorough peer review

- No space constraints or color figure charges

- Immediate publication on acceptance

- Inclusion in PubMed, CAS, Scopus and Google Scholar

- Research which is freely available for redistribution
() Biomed Central

(c) 2015 Sjölander et al; licensee BioMed Central Ltd. This is an Open Access article distributed under the terms of the Creative Commons Attribution License (http://creativecommons.org/licenses/by/4.0), which permits unrestricted use, distribution, and reproduction in any medium, provided the original work is properly cited. The Creative Commons Public Domain Dedication waiver (http://creativecommons.org/publicdomain/zero/1.0/) applies to the data made available in this article, unless otherwise stated. 